\title{
HUBUNGAN ANTARA TINGKAT STRES DENGAN SIKLUS MENSTRUASI PADA MAHASISWI TINGKAT II A AKADEMI KEPERAWATAN PANTI KOSALA SURAKARTA
}

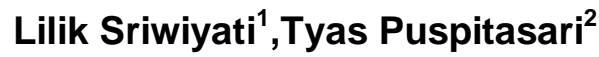

\begin{abstract}
Stress is any situation where the nonspecific demands requires an individual to respond or take action. Stress can affect the menstrual cycle, because in times of stress, the hormone cortisol as a product of glukokortiroid adrenal cortex may affect the amount of progesterone in the body. Purpose of this research is to seek the relation between stress level with menstrual cycle on student level II A in Panti Kosala Nursing Academi.

Subjects of this research were the student level II A in Panti Kosala Nursing Academi. The samples were 30 respondents selected by using purposive sampling method. Method of the research is a corelational study. This research has two variables, the independent variable is stress level and the dependent variable is menstrual cycle. Collecting data use questionnaire paper. Data analysis use Chi Quadrat Test with $\mathrm{p}=0.05$.

Results of this research are shown that there were 11 respondents who have a mild stress, 5 people as normal menstrual cycles, 4 people as polymenorhea and 2 people as oligomenorrhea. Respondents who have average stress about 18 people, 13 people as normal menstrual cycles and 5 people as oligomenorrhea. While respondents who have severe stress as much as one person with the menstrual cycle is oligomenorrhea. Statistical test use Chi Quadrat with the result $p=0.031$.

The Conclusion of this research is that there is a relation between stress level with the menstrual cycle on student level II A in Panti Kosala Nursing Academi.
\end{abstract}

Keywords: stress level, menstrual cycles

\section{PENDAHULUAN}

Menurut Nasir dan Muhith (2011) stres merupakan hal yang menjadi bagian dari kehidupan manusia. Stres adalah reaksi dari tubuh (respons) terhadap lingkungan yang dapat memproteksi diri, yang juga merupakan bagian dari sistem pertahanan yang membuat tetap hidup.

Menstruasi adalah pengeluaran cairan dari vagina secara berkala selama masa usia reproduktif. Biasanya berlangsung selama 3 - 7 hari (Ramaiah, 2006).

Siklus mensturasi merupakan waktu sejak hari pertama mensturasi sampai datangnya mensturasi periode berikutnya, sedangkan panjang siklus mensturasi adalah jarak antara tanggal mulainya mensturasi yang lalu dan mulainya mensturasi berikutnya. Siklus mensturasi pada wanita normalnya berkisar antara 21 - 32 hari dan hanya $10-15 \%$ yang memiliki siklus mensturasi 28 hari dengan lama mensturasi 3 - 5 hari, ada yang 7 - 8 hari (Proverawati dan Misaroh, 2009).

Menurut penelitian yang dilakukan oleh Isnaeni (2010) tentang Hubungan Tingkat Stres dengan Siklus Menstruasi pada 89 responden. Didapatkan responden yang mengalami stres ringan adalah 62 responden (84.93\%), dengan perincian siklus menstruasi normal sebanyak 55 responden (88.70\%), 2 responden $(2.74 \%)$ dengan siklus menstruasi polymenorrhea, 4 
responden $(2.74 \%)$ dengan siklus menstruasi oligomenorrhea.

Berdasarkan hasil survei awal di Akademi Keperawatan Panti Kosala Surakarta, yang dilakukan pada 20 mahasiswi yang mengalami menstruasi, hasil survei yang didapatkan adalah sejumlah 18 mahasiswi mengalami stres ringan dan 2 mahasiswi mengalami stres sedang, 8 responden dengan tingkat stres ringan mengalami siklus menstruasi kurang dari 21 hari, 10 responden dengan tingkat stres ringan mengalami siklus menstruasi 21-35 hari, dan 2 responden dengan tingkat stres sedang mengalami siklus menstruasi lebih dari 35 hari. Siklus menstruasi tersebut dihitung sejak hari pertama menstruasi pada bulan sebelumnya.

\section{TUJUAN PENELITIAN}

Tujuan penelitian ini secara umum adalah untuk mengetahui hubungan antara tingkat stres dengan siklus menstruasi, dan secara khusus untuk mengetahui tingkat stres mahasiswi tingkat II A, siklus menstruasi mahasiswi tingkat II A dan menganalisis hubungan antara tingkat stres dengan siklus menstruasi.

\section{METODE/DESAIN PENELITIAN}

Penelitian ini menggunakan desain penelitian korelasi untuk mengetahui hubungan tingkat stres dengan siklus menstruasi pada Mahasiswi Tingkat II A Akademi Keperawatan Panti Kosala Surakarta. Penelitian ini terdiri dari dua variabel yaitu tingkat stres sebagai variabel bebas (independent variable) dan siklus menstruasi sebagai variabel terikat (dependent variable).

\section{POPULASI, SAMPEL, DAN TEKNIK SAMPLING}

Populasi pada penelitian ini adalah mahasiswi tingkat II A Akademi Keperawatan Panti Kosala Surakarta, yaitu sebanyak 33 mahasiswi. Besar sampel pada penelitian ini adalah 30 mahasiswi yang diambil dengan menggunakan teknik purposive sampling. Kriteria inklusi dalam penelitian ini adalah Mahasiswi tingkat II A Akademi Keperawatan Panti Kosala Surakarta, bersedia menjadi responden, sedang mengalami menstruasi, dan tidak mempunyai riwayat ganguuan reproduksi. Sedangkan kriteria eksklusi dalam penelitian ini adalah mahasiswi yang mempunyai riwayat gangguan reproduksi dan mempunyai riwayat siklus menstruasi tidak normal.

\section{HASIL PENELITIAN}

1. Karakteristik Responden

Tabel 1.

Distribusi Frekuensi Karakteristik Responden berdasarkan Usia

\begin{tabular}{ccc}
\hline Umur $($ Th $)$ & $f$ & $\%$ \\
\hline 18 & 1 & 3.3 \\
19 & 19 & 64.4 \\
20 & 9 & 30.0 \\
21 & 1 & 3.3 \\
\hline Jumlah & 30 & 100 \\
\hline
\end{tabular}

Tabel di atas menunjukkan bahwa berdasarkan umur responden paling banyak berumur 19 tahun yaitu berjumlah 19 responden $(64.4 \%)$.

2. Tingkat Stres

Tabel 2.

Distribusi frekuensi tingkat stres responden

\begin{tabular}{lcc}
\hline Tingkat stres & $\mathrm{f}$ & $\%$ \\
\hline Stres ringan & 11 & 37.7 \\
Stres sedang & 18 & 60.0 \\
Stres berat & 1 & 3.3 \\
\hline Jumlah & 30 & 100 \\
\hline
\end{tabular}

Berdasarkan tabel di atas dapat diketahui bahwa sejumlah 11 (37.7\%) responden memiliki tingkat stres ringan, 18 (60\%) responden memiliki tingkat stres sedang, dan 1 (3.3\%) responden memiliki tingkat stres berat. 
3. Siklus Menstruasi

Tabel 3.

Distribusi frekuensi siklus menstruasi responden

\begin{tabular}{lcc} 
Siklus & $f$ & $\%$ \\
menstruasi & 4 & 13.3 \\
Polymenorrhea & 18 & 60 \\
Normal & 8 & 26.7 \\
Oligomenorrhea & 30 & 100 \\
\hline Jumlah & &
\end{tabular}

Berdasarkan tabel di atas dapat diketahui bahwa 4 (13.3\%) responden memiliki siklus menstruasi polymenorrhea, 18 $(60 \%)$ responden memiliki siklus menstruasi normal dan 8 (26.7\%) lainnya memiliki siklus menstruasi oligomenorrhea.

4. Hasil Tabulasi Silang Hubungan antara Tingkat Stres dengan Siklus Menstruasi

Tabel 4.

Tabulasi Silang Hubungan antara Tingkat Stres dengan Siklus Menstruasi

\begin{tabular}{lcccc}
\hline \multirow{2}{*}{$\begin{array}{l}\text { Tingkat } \\
\text { Stres }\end{array}$} & $\begin{array}{c}\text { Siklus Menstruasi } \\
\text { Moly }\end{array}$ & $\begin{array}{c}\text { Nor } \\
\text { Meno }\end{array}$ & $\begin{array}{c}\text { Oligo } \\
\text { mal }\end{array}$ & $\begin{array}{c}\text { Meno } \\
\text { rhea }\end{array}$ \\
\hline Ringan & 4 & 5 & rhea & \\
Sedang & 0 & 13 & 5 & 11 \\
Berat & 0 & 0 & 1 & 1 \\
\hline Total & 4 & 18 & 8 & 30 \\
\hline
\end{tabular}

Berdasarkan tabel di atas dapat diperoleh data bahwa mahasiswi yang memiliki tingkat stres ringan sejumlah 11 (36.7\%) dimana 4 (13.3\%) mengalami polymenorrhea, $5 \quad(16.7 \%)$ mengalami siklus normal sedangkan $2 \quad(6.7 \%)$ lainnya mengalami siklus oligomenorrhea. Jumlah mahasiswi yang memiliki tingkat stres sedang adalah 18 (60.0\%) dimana $13(43.3 \%)$ mengalami siklus normal dan 5 (16.7\%) mengalami siklus oligomenorrhea. Sedangkan jumlah mahasiswi yang memiliki tingkat stres berat adalah 1 (3.3\%) dimana mengalami siklus oligomenorrhea.

Berdasarkan hasil uji Chi-Square program SPSS versi 18.0 dengan $\alpha=5 \%(0.05)$ diperoleh $p$ sebesar 0.031 sehingga nilai $p<$ 0.05 , yang berarti $\mathrm{Ha}$ diterima dan $\mathrm{H}_{\mathrm{o}}$ ditolak, sehingga dapat disimpulkan bahwa ada hubungan tingkat stres dengan siklus menstruasi pada mahasiswi tingkat II A AKPER Panti Kosala Surakarta.

\section{PEMBAHASAN}

Berdasarkan hasil penelitian dapat dicermati bahwa sejumlah 11 $(36.7 \%)$ responden memiliki tingkat stres ringan, $18(60 \%)$ responden memiliki tingkat stres sedang, dan 1 (3.3\%) responden memiliki tingkat stres berat. Hal ini menunjukkan bahwa mayoritas mahasiswi tingkat II A AKPER Panti Kosala Surakarta mengalami stres sedang .

Menurut Selye sebagaimana dikutip oleh Potter dan Perry (2005), stres adalah segala situasi dimana tuntutan non spesifik mengharuskan seorang individu untuk berespon atau melakukan tindakan. Stres dapat menyebabkan perasaan negatif atau yang berlawanan dengan apa yang diinginkan atau mengancam kesejahteraan emosional. Stres dapat mengganggu cara seseorang dalam menyerap realitas, menyelesaikan masalah, hubungan seseorang dan rasa memiliki. Selain itu stres dapat mengganggu pandangan umum seseorang terhadap hidup, sikap terhadap orang yang disayangi dan status kesehatan.

Faktor-faktor presipitasi stres menurut Nasir dan Muhith (2011) meliputi faktor fisik dan biologis, seperti genetika, pengalaman hidup, tidur, diet, postur tubuh dan penyakit. Selain faktor fisik dan biologis juga terdapat faktor psikologis, seperti persepsi dan 
emosi, serta ada juga faktor lingkungan.

Berdasarkan survei tingkat stres, didapatkan hasil bahwa mayoritas $(60 \%)$ mahasiswi tingkat II A mengalami stres sedang. Responden yang mengalami stres tersebut mayoritas merasakan gejala stres seperti merasa letih sewaktu bangun pagi, merasa lekas lelah menjelang sore hari, mengeluh lambung/perut tidak nyaman, merasa tegang, mengalami gangguan pola tidur, merasa takut dan cemas serta merasa konsentrasi menurun. Menurut responden mereka mengalami kondisi-kondisi tersebut dikarenakan oleh padatnya jam perkuliahan, tugas yang banyak dari masingmasing mata kuliah, serta adanya pre tes ataupun post test yang dilakukan di masing-masing mata kuliah.

Menurut Robert sebagaimana dikutip oleh Hawari (2006) gejala stres meliputi merasa letih sewaktu bangun pagi yang seharusnya merasa segar, lekas merasa lelah menjelang sore hari, sering mengeluh lambung/perut tidak nyaman (bowel discomfort), detakan jantung lebih keras dari biasanya (berdebar-debar), otot-otot punggung dan tengkuk akan terasa lebih tegang, perasaaan tidak tenang dan ketegangan emosional semakin meningkat, gangguan pola tidur (insomnia), koordinasi tubuh terganggu (badan terasa akan jatuh dan serasa mau pingsan), ketidakmampuan untuk melaksanakan kegiatan rutin seharihari, timbul perasaan ketakutan, kecemasan yang semakin meningkat, mudah bingung dan panik, susah bernapas, sekujur badan terasa gemetar, dingin dan keringat bercucuran, ketiadaan tenaga untuk hal-hal yang ringan. Berdasarkan teori tersebut maka dapat diketahui bahwa responden mengalami gejala-gejala stres.
Berdasarkan survey siklus menstruasi dapat diketahui sejumlah $4(13.3 \%)$ responden memiliki siklus menstruasi polymenorrhea, 18 $(60 \%)$ responden memiliki siklus menstruasi normal dan 8 (26.7\%) lainnya responden memiliki siklus menstruasi oligomenorrhea.

Menurut Toduho, Kundre dan Malara (2013), siklus menstruasi merupakan waktu sejak hari pertama menstruasi sampai datangnya menstruasi periode berikutnya, sedangkan panjang siklus menstruasi adalah jarak antara tanggal mulainya menstruasi yang lalu dan mulainya menstruasi berikutnya. Umumnya siklus menstruasi terjadi secara periodik setiap 28 hari. Kusmiran (2012) menyebutkan macam-macam gangguan siklus menstruasi yaitu amenorrhea, oligomenorrhea, dan polymenorrhea. Amenorrhea adalah tidak adanya menstruasi. Kategori amenorrhea primer jika pada wanita di usia 16 tahun belum mengalami menstruasi, sedangkan amenorrhea sekunder adalah yang terjadi setelah menstruasi. Oligomenorrhea adalah tidak adanya menstruasi untuk jarak interval yang pendek atau tidak normalnya jarak waktu menstruasi yaitu jarak siklus menstruasi $\quad 35-90$ hari. Polymenorrhea adalah sering menstruasi yaitu jarak siklus menstruasi yang pendek kurang dari 21 hari.

Hasil penelitian yang telah dilakukan terkait dengan siklus menstruasi didapatkan mayoritas responden memiliki siklus menstruasi normal, yaitu antara 21-35 hari, akan tetapi ada responden yang mengalami gangguan siklus menstruasi yaitu ada yang mengalami siklus menstruasi kurang dari 21 hari dan ada juga yang mengalami siklus menstruasi lebih dari 35 hari.

Kusmiran (2012) menjelaskan bahwa gangguan siklus menstruasi dipengaruhi oleh adanya defek pada 
fase luteal yang menyebabkan tidak adekuatnya sekresi atau kerja dari hormon progesteron sehingga mengganggu proses siklus menstruasi di endometrium.

Hasil analisis bivariat antara tingkat stres dengan siklus menstruasi menunjukkan hasil bahwa terdapat 11 responden yang mengalami stres ringan, dengan siklus menstruasi normal sebanyak 5 orang, polymenorrhea sebanyak 4 orang dan oligomenorrhea sebanyak 2 orang. Responden yang mengalami stres sedang sebanyak 18 orang, dengan siklus menstruasi normal sebanyak 13 orang, oligomenorrhea sebanyak 2 orang dan tidak ada yang mengalami polymenorrhea. Sedangkan responden yang mengalami stres berat sebanyak 1 orang dengan siklus menstruasi oligomenorrhea. Hal tersebut menunjukkan bahwa responden dengan tingkat stres ringan, sedang maupun berat ada sebagian yang mengalami perubahan siklus menstruasi yaitu polymenorrhea atau oligomenorrhea.

Menurut Kusmiran (2012) faktor yang mempengaruhi menstruasi meliputi faktor hormon, enzim, vaskuler dan prostaglandin. Stres dapat menyebabkan perubahan sistemik dalam tubuh, khususnya sistem persarafan dalam hipotalamus melalui perubahan prolaktin atau endogenous opiat yang dapat mempengaruhi elevasi kortisol basal dan menurunkan hormon lutein (LH) yang menyebabkan amenorrhea. Menurut Wiknjosastro (2007), siklus menstruasi dipengaruhi oleh serangkaian hormone yang diperoleh oleh tubuh yaitu Leuteinizing Hormon, Follicle Stimulating Hormon Estrogen. Selain itu siklus juga dipengaruhi oleh kondisi psikis sehingga bisa maju dan mundur. Toduho, Kundre dan Malara (2013) mengungkapkan bahwa stres dapat mempengaruhi siklus menstruasi, karena pada saat stres, hormon kortisol sebagai produk dari glukokortiroid korteks adrenal yang disentesa pada zona fasikulata, dapat mempengaruhi jumlah hormon progesteron dalam tubuh. Jumlah hormon dalam darah yang terlalu banyak inilah yang dapat menyebabkan perubahan siklus menstruasi.

Setelah dilakukan uji statistik hubungan tingkat stres dengan siklus menstruasi menggunakan uji Chi-Square program SPSS versi 18.0 dengan $\alpha=5 \%$ (0.05) diperoleh $p$ sebesar 0.031 . Karena nilai $p<$ 0.05, maka Ho ditolak dan $\mathrm{H}_{\mathrm{a}}$ diterima, sehingga penelitian ini menunjukkan bahwa ada hubungan antara tingkat stres dengan siklus menstruasi pada mahasiswi tingkat II A AKPER Panti Kosala Surakarta.

Hasil penelitian ini juga sesuai dengan penelitian terdahulu yang dilakukan oleh Mulastin (2013) dengan judul Hubungan antara Stres dengan Siklus Menstruasi pada Wanita Pekerja di Desa Pelemkerep Kecamatan Mayong Kabupaten Jepara. Penelitian dilakukan pada 62 responden dengan menggunakan teknik purposive sampling. Analisa hasil penelitian dengan Chi-Square, diperoleh hasil $\rho$ value $0.000<$ (0.01) berarti ada Hubungan antara Stres dengan Siklus Menstruasi pada Wanita Pekerja di Desa Pelemkerep Kecamatan Mayong Kabupaten Jepara.

Penelitian lain yang memiliki hasil yang sama adalah penelitian yang dilakukan oleh Toduho, Kundre dan Malara (2013) dengan judul Hubungan Stres Psikologi dengan Siklus Menstruasi pada Siswi Kelas 1 di SMA Negeri 3 Kepulauan Tidore. Desain penelitian menggunakan metode deskriptif analitik dengan menggunakan rancangan cross sectional study. Penelitian dilakukan pada 68 responden dengan menggunakan 
teknik purposive sampling. Hasil penelitian diolah menggunakan uji Chi-Square $\left(\mathrm{X}^{2}\right)$, dengan tingkat kemaknaan $95 \%(\alpha \leq 0.05)$ dan didapat nilai $p=0.000$. Dari hasil tersebut berarti ada Hubungan antara Stres dengan Siklus Menstruasi pada Siswi Kelas 1 di SMA Negeri 3 Kepulauan Tidore.

\section{KESIMPULAN}

1. Karakteristik responden: Tingkat stres mahasiswi mayoritas pada kategori sedang sejumlah sejumlah 18 (60\%) dengan siklus menstruasi mayoritas adalah normal yaitu 18 (60\%).

2. Secara Statistik:

Hasil uji statistik menggunakan uji Chi-Square dengan $\alpha=5 \%$ (0.05) diperoleh $p$ sebesar 0.031 sehingga nilai $p<0.05$, yang berarti ada Hubungan Tingkat Stres dengan Siklus Menstruasi pada Mahasiswi Tingkat II A AKPER Panti Kosala Surakarta.

\section{SARAN}

1. Bagi remaja putri diharapkan sedapat mungkin menghindari stres supaya siklus menstruasi tidak terganggu karena adanya perubahan hormonal akibat stres.

2. Bagi tenaga kesehatan diharapkan dapat meningkatkan pemberian informasi kepada para remaja putri terkait dengan kesehatan reproduksi, khususnya tentang siklus menstruasi dan faktor-faktor yang mempengaruhi.

\section{DAFTAR PUSTAKA}

Adriaansz, H. Wiknjosastro dan Waspodo. 2007. Buku Acuan Nasional Pelayanan Kesehatan Maternal dan Neonatal. Yayasan Bina Pustaka Sarwono Prawiroharjdo, Jakarta.

Hawari, D. 2006. Manajemen Stres, Cemas dan Depresi. Fakultas
Kedokteran Universitas Indonesia, Jakarta.

Isnaeni, D.N. 2010. Hubungan antara Stres dengan Pola Menstruasi pada Mahasiswi $D$ IV Kebidanan Jalur Reguler Universitas Sebelas Maret Surakarta. URL: http//jurnal.eprints.uns.ac.id.

Diakses tanggal 3 Oktober 2015

Kusmiran, E. 2012. Kesehatan Reproduksi Remaja dan Wanita. Salemba Medika, Jakarta.

Mulastin. 2013. Hubungan Stres dengan Siklus Menstruasi pada Wanita Pekerja di Desa Pelemkereb Kecamatan Mayong Kabupaten Jepara. URL: $\quad$ http//jurnal.akbidal hikmah.ac.id. Diakses tanggal 2 Oktober 2015

Nasir, A. dan A. Muhith. 2011. Dasar-Dasar Keperawatan Jiwa. Salemba Medika, Jakarta.

Potter, P. A. dan A. G. Perry. 2005. Buku Ajar Fundamental Keperawatan, ed 7. Alih Bahasa : Diah Nur Fitriani, Onny Tampubolon, dan Farah Diba. EGC, Jakarta.

Proverawati, A.,dan S. Misaroh, Siti. 2009. Menarche Menstruasi Pertama penuh Makna. Nuha Medika, Yogyakarta.

Ramaiah, S. 2006. Mengatasi Gangguan Menstruasi. Diglosia Medika, Yogyakarta.

Toduho, K., R. Kundre dan R. Malara. 2013. Hubungan Stres Psikologis dengan Siklus Menstruasi pada Siswi Kelas 1 di SMA Negeri 3 Kepulauan Tidore URL http://jurnalstikes.com. Diunduh tanggal 3 Oktober 2015.

\footnotetext{
${ }^{1}$ Dosen Akper Panti Kosala

Surakarta

${ }^{2}$ Mahasiswa Akper Panti Kosala Surakarta
} 